\title{
LIFE COURSE PERSPECTIVE OF THE FACTORS AFFECTING OVERWEIGHT AND OBESITY IN CHILDREN UNDER FIVE: A PATH ANALYSIS EVIDENCE FROM SURAKARTA
}

\author{
Uyunun Nudhira'), Cri SPWekadigunawan²), Bhisma Murti1) \\ ${ }^{1)}$ Masters Program in Public Health, Universitas Sebelas Maret \\ 2) Faculty of Medicine, Universitas Sebelas Maret
}

\begin{abstract}
Background: Obesity is a public health problem that has raised concern worldwide. According to the World Health Organization, there will be about 2.3 billion overweight people aged 15 years and above, and over 700 million obese people worldwide in 2015. Being overweight or obese in childhood can contributes to numerous health conditions in adulthood including: hypertension, high LDL cholesterol, low HDL cholesterol or high levels of triglycerides, type 2 diabetes, coronary heart disease, and stroke. This study aimed to analyze the life course factors affecting overweight and obesity in children aged 2 to 5 years old in Surakarta, Central Java.
\end{abstract}

Subjects and Method: This was a case control study was conducted in 5 community health centers, Surakarta, Central Java, from September to October 2017. A sample of 150 children aged 2 to 5 years old was selected for this study by fixed disease sampling. The dependent variable was overweight or obesity. The independent variables were nutrition intake, exclusive breastfeeding, starting age of complementary feeding, physical activity, birthweight, age of gestation, sectio cesarea labor, maternal body mass index, and maternal job. Physical activity data was measured using Pre PAQ questionnaire. Other data were collected using a set of questionnaire and maternal and child health monitoring book. The data were analyzed by path analysis.

Results: Overweight and obesity in children aged 2 to 5 years old were positively affected by over nutrition intake $(b=1.9 ; 95 \% \mathrm{CI}=0.15$ to $3.60 ; \mathrm{p}=0.033)$, high maternal body mass index $(b=2.0 ; 95 \% \mathrm{CI}=0.51$ to $3.42 ; \mathrm{p}=0.008)$, and sectio cesarean birth $(b=2.1 ; 95 \% \mathrm{CI}=0.56$ to $3.73 ; \mathrm{p}=0.008)$. Overweight and obesity in children aged 2 to 5 years old were negatively affected by normal birthweight $(b=-2.2 ; 95 \% \mathrm{CI}=-4.28$ to $-0.19 ; \mathrm{p}=0.032)$, exclusive breastfeeding $(\mathrm{b}=-2.0$; $95 \% \mathrm{CI}=-3.60$ to $-0.39 ; \mathrm{p}=0.015)$, timely starting age of complementary feeding $(\mathrm{b}=-1.3 ; 95 \% \mathrm{CI}=-2.80$ to $0.11 ; \mathrm{p}=0.072)$, and high physical activity $(\mathrm{b}=-3.0$; $95 \% \mathrm{CI}=-4.63$ to $-1.37 ; \mathrm{p}=0.001$ ). Overweight and obesity in children aged 2 to 5 years old were indirectly affected by age of gestation and working outside the house.

Conclusion: Overweight and obesity in children aged 2 to 5 years old are positively affected by over nutrition intake, high maternal body mass index, and sectio cesarean birth. Overweight and obesity in children aged 2 to 5 years old are negatively affected by normal birthweight, exclusive breastfeeding, timely starting age of complementary feeding, and high physical activity.

Keywords: life course factors, overweight, obesity, path analysis.

\section{Correspondence:}

Uyunun Nudhira. Masters Program in Public Health, Universitas Sebelas Maret, Jl. Ir. Sutami 36 A, Surakarta 57126, Central Java.

Email: uyununnudhira14@gmail.com. Mobile: +6285253781714.

Mid-International Conference in Public Health, Best Western Premiere Hotel, Solo, Indonesia, 18-19 April 2018 | 67 https://doi.org/10.26911/mid.icph.2018.01.04 